\title{
The Value of New: Elementary School Facility Age and Associated Housing Price Huston Gibson
}

\section{Abstract}

The purpose of this article is to assess the relationship between elementary school facility age and single-family housing price in the Orlando, Florida metropolitan area. This is a cross-sectional study employing multivariate regression. The model includes facility age as a measure of perceived school quality, along with a series of control variables to assess the relationship between public elementary school facility age and the corresponding housing prices within the associated school attendance zones. This study provides evidence that housing prices are associated with school facility age. The findings show housing prices to be positively correlated with newer and historic school facilities.

This paper explores the association between public elementary school facility age and housing price. New, historic, and in-between school facility age categories are explored, both in terms of age built/constructed and average facility age, weighted by net square feet to account for additions and remodeling. The perception of the school's descriptive categorical age influences its desirability and thereby the associated selling prices of housing in the school attendance zone. The findings pertain to public elementary schools; however, additional analysis of middle and high schools result in fairly similar findings.

A person's home is one of the single largest financial investments he or she will make for themselves and their family (United States Department of Housing and Urban Development, 1995). Therefore, it is rational to assume that property market value is a subject of reasonable importance. This makes research investigating the influences on housing value a topic of great relevance. One of the influences on housing price is commonly thought to be school quality (Jud and Watts, 1981). The relationship between school quality and housing choice is seemingly bi-directional and multi-dimensional, although the most basic explanation of the relationship is an underlining desire by parents to send their children to "good" schools.

Education is an access to opportunity for children (Briggs, 2005). Due to the importance of education, parents will seek out housing in the best school zone they can afford, net of other decision factors (Tiebout, 1956; Fischel, 2000; Briggs, 2005). Essentially, when shopping for housing many consumers will simultaneously shop for schools, deciding whether or not to pay higher home prices to live in better school zones (Tiebout, 1956; Fischel, 2000). In addition, households without children in the K-12 public school system are suspected to also want to capitalize on a perceivably good school zone via the solid resale value (Jud and Watts, 1981; Briggs, 2005). One of the best measures of desirability 
for any commodity is the price that someone is willing to pay. With respect to housing studies, school quality has been referred to as "the most important cause of the variation in constant-quality house prices," (Haurin and Brasington, 1996, p. 363).

Though the exact root, or even the extent, of this effect is one of debate, school quality is repeatedly professed to influence housing price. The relationship between school quality and housing price is widely discussed in the literature. Several studies in various locations in the United States have relatively similar findings, suggesting a significant and positive relationship between school quality and housing value (Kain and Quigley, 1970; Li and Brown, 1980; Jud and Watts 1981; Diyab, 1984; Haurin and Brasington, 1996; Hayes and Taylor 1996; Bogart and Cromwell, 1997; Bradbury, Case, and Mayer, 1998; Goodman and Thibodeau, 1998; Black, 1999; Clark and Herrin, 2000; Weimer and Wolkoff, 2001; Downes and Zabel, 2002; Figlio and Lucas, 2004; Reback, 2005; Brasington and Haurin, 2006; Harrison, 2006; Seo and Simons, 2009). Yet critically, previous studies addressing school quality on housing prices limit their considerations to mostly test scores (and variations of), with only some limited auxiliary emphasis on "perceptions," socioeconomic characteristics, school finances, and student/teacher ratios. This is problematic because they do not include a full range of facility attributes, such as facility age.

There is evidence suggesting that a school facility's age, its physical condition, and its associated available resources affect a student's education (Plumley, 1978; Chan, 1979; Bowers and Burkett, 1987; Ikpa, 1992; Cash, 1993; Betts, 1995; Hines, 1996; Summers and Wolfe, 1977; Harter, 1999; Morgan, 2001; Schneider, 2002). Perhaps this is why it has more recently become a recurring theme that newer built schools are generally perceived to be better than older schools. This is likely due to the assumption that newer schools will have "better" facilities and possess more current, and thereby "better," technological resources compared to older facilities (Betts, 1995; Schneider, 2002; Baum, 2004; Gurwitt, 2004; Briggs, 2005).

Jurisdictions have not been blind to the positive association between school quality and housing choice. Several jurisdictions recognize the linkage between having an attractive school system and residential location desirability. Cincinnati has sought to capitalize on this phenomenon by increasing expenditures to city school programs, helping to create residential desirability within the city (Varady and Raffel, 1995). Cities like Pomona (CA), Philadelphia (PA), and Chattanooga (TN) also acknowledge the importance of school quality by incorporating schools in their community revitalization plans. Pomona recognizes the positive reaction new public elementary and high schools make to distressed areas, stating they help 'jump start' revitalization by creating desirability for housing in the surrounding neighborhoods. Philadelphia and Chattanooga report similar experiences (Weiss, 2004).

In a policy piece advocating the coupling of smart growth principles with school reform, Baum (2004) focuses on education, inferring that improving inner city schools could be a tool in managing sprawl. In his article, he argues that if inner city schools are renovated when expanded facilities are needed instead of building new schools in suburban areas, this may not only help curb sprawl, but further racial desegregation in the public school system. The underlining suggestion is that "new" and "good" are being perceived to be synonymous when it comes to school facilities, thereby making the renovated facilities attractive (Baum, 2004). 
In 2001, the Urban Land Institute (ULI) held a forum on Sustaining Urban Mixed-Income Communities with the emphasis on the role of community facilities. This forum concluded that community facilities, specifically schools, are vital in community revitalization efforts. One project in St. Louis uses the remodeling of an elementary school as the focal point of a neighborhood revitalization project. A large component of the renovation was increasing the technology resources in the school facility. Another project in Atlanta built a new elementary school as part of its neighborhood revitalization efforts. A representative from the Atlanta project advocates that this (new) school is the most significant aspect of the entire project, aiding in changing the actual overall perceptions of the neighborhood. They claim that, "in addition to providing an important educational resource for neighborhood children, the [new] school has helped to change the perception of the community," (Myerson, 2001, p. 5). This quote from Atlanta encapsulates the crux of this article.

\section{Significance of the Study, Central Research Question, and Hypothesis}

Despite evidence suggesting the school facility to be important to a child's education, the notion that new school facilities are desirable for reasons of perceived quality, the ample amount of research and literature regarding the association of school quality and housing price, there is no known study that looks specifically at the relationship between school facility age and its association with housing price. The significance of this paper is the inclusion of facility age as a measure of how school quality perceptions via facility age, may influence housing price. The central research question addressed is: Is there a relationship between school facility age and home selling price; and, if so, what is the direction and magnitude of this relationship? The central hypothesis tested is: School facility age has a significant inverse relationship with housing price, due to 'newer equals better' perceptions.

Inclusion of facility age expands theoretical and policy discourse by helping to better understand how the investment of public resources (via new schools), if built in older communities as part of community development initiatives, might aid in urban revitalization efforts. The implication is that if communities invest in new schools, or renovate schools in older communities, then this could aid in community development initiatives and urban revitalization efforts in those neighborhoods. Consequently, and of equal importance, the lack of school investment in already disadvantaged parts of a region could aid in further economic decline and perpetuate socio-economic community divisions in that region.

\section{Sample}

The unit of analysis is the detached single-family house. Housing price differences can be compared most directly when comparing a uniformed housing style, such as a detached single-family house to another detached single-family house, as opposed to a detached single-family house to an attached townhouse or multi-family apartment building. While it is possible to conduct this study with another uniform housing style as the unit of analysis, the detached single-family house is the most common type of residence in the 
U.S., and therefore is the most representative (United States Census Bureau, 2007). In addition, previous studies addressing school quality-housing value relationships often use the detached single-family house as their unit of analysis. In an effort to conform the findings of this study to best fit the ongoing discourse on the matter, the same unit of analysis as the previous studies is used. The study population is a sample of all owneroccupied, primary detached single-family housing transactions recorded as an arms-length transaction, in the Orlando, Florida area (Orange and Seminole Counties) during 2005. Within Orange and Seminole Counties there are two (countywide) school districts and a total of 146 elementary school facilities (111 in Orange County and 35 in Seminole). Exhibit 1 displays the county/school district boundaries, with municipality boundaries.

Orlando is considered to be a city of national interest and the metropolitan area contains multiple municipal and county jurisdictions, making the area appropriate for study. Having more than one county jurisdiction in the study is important because the school districts are countywide, and property tax rolls in Florida are grouped at the county level as well. This in turn controls for variations in county attributes, such as county property appraisers and millage rates, school boards and superintendents, or other countywide boards, commissions, and/or organizations.

In addition to being home to Walt Disney World and several other international attractions, part of the reason the Orlando area is considered to be of national interest for a study such as this is because the region's residential dwellings are mostly singlefamily, primary residences, and considered to be suburban in nature, similar to the typical habitat for the majority of the U.S. population (United States Census Bureau, 2007). Orlando is a non-coastal city, and this also helps the findings and conclusions to be reasonably generalizable in an American context.

Based on Census population estimates from July 1, 2005, Orange County, home to Orlando, housed 1,030,456 persons with 215,190 persons residing in the City of Orlando. Neighboring Seminole County, a major bedroom community of the Orlando area, housed 403,120 persons in the July 1, 2005 estimate. Combined, Orange and Seminole County collectively house 1,433,576 people as of July 1, 2005 (United States Census Bureau, 2008). Together, these two counties make up the geographic boundary of this study, giving the study a large dataset with spatial and jurisdictional variation. ${ }^{1}$

The sample frame includes all owner-occupied, primary detached single-family housing selling prices as recorded by the local county property appraiser's office for Orange and Seminole counties during 2005. This data set is chosen because 2005 is the last full stable year before the housing market started to deflate in 2006 (Birger, 2006). The reason for using recorded housing selling prices instead of assessed values is because open market transactions are thought a more accurate representation of the "truest" value, based on willingness to pay.

In 2005, there were 206 total public schools in the study area; 141 of these are elementary schools, 41 middle schools, and 24 high schools. Elementary pertains to grades $\mathrm{K}$ (kindergarten) though five, middle pertains to grades six through eight, and high pertains to grades nine through twelve. Each home is zoned for one elementary school, one middle school, and one high school. For analysis, the school age associating with the house is based on the 2005 school district attendance boundary zoning. Each classification of 


\section{Exhibit 1. Orlando, Florida Area Cities}

\section{Legend}

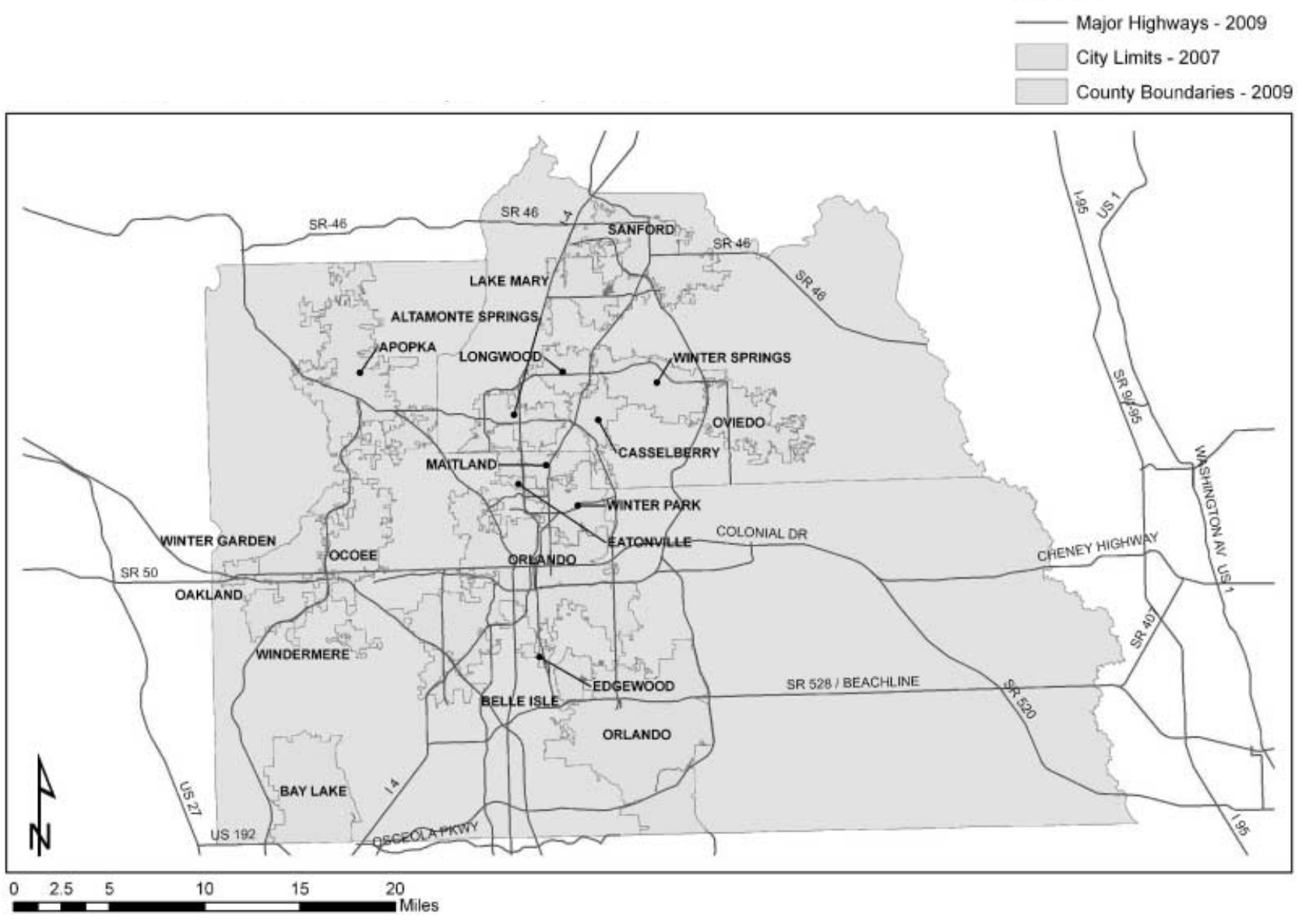

m

受 
school is analyzed separately, and all three school types produce relatively similar results. The findings on display pertain to public elementary schools.

\section{Statistical Model}

Hedonic price modeling estimates a consumer's willingness to pay for a product as a result of a product's collective features, and produces intuitive interpretable results allowing the added value of each included feature to be assessed separately (Sirmans, Macpherson, and Zietz, 2005). In this case the selling price of a house is considered to be the result of the attractiveness of its associated housing and neighborhood characteristics (such as the size of the house, or the associated elementary school). Some critics claim there are too many explanatory variables in hedonic equations, or too much methodological "noise" for accuracy (Wetzel, 1983). Yet, standard hedonic price modeling is a common methodological approach for housing price research both historically and currently; from one of the earliest studies showing school quality to be associated with monetary housing value, to one of the more recent Journal of Housing Research articles investing the effects of gated streets on housing prices (Kain and Quigley, 1970; LaCour-Little and Malpezzi, 2009). The vast commonality of this approach helps make the findings widely applicable to the ongoing discourse regarding effects on housing price, the discussion of aim; and thereby is considered appropriate for the aim of this study.

The basic hedonic price model assumes that price is a function of a product's physical characteristics plus all other associated factors (Sirmans, Macpherson, and Zietz, 2005). Building on this principle, this cross-sectional study employs multivariate regression to investigate the association of school facility age on housing price. The regression model is as follows:

$$
\begin{aligned}
\text { Selling Price } & =B_{0}+B_{1}(\text { School Facility Age })^{*}+B_{2}(\text { School Output }) \\
& +B_{3}(\text { Title I Status })+B_{4}(\text { Student Minority Rate }) \\
& +B_{5}(\text { Faculty Experience })+B_{6}(\text { Classroom Technology }) \\
& +B_{7}(\text { Class Size })+B_{8}(\text { Facility Size })+B_{9}(\text { School Capacity }) \\
& +B_{10}(\text { School District })+B_{11}(\text { Proximate to Alternative School }) \\
& +B_{12}(\text { Living Space of House })+B_{13}(\text { Age of House }) \\
& +B_{14}(\text { Lot Size })+B_{15}(\text { Special Housing Features }) \\
& +B_{16}(\text { Jurisdictional Service Fee Rate }) \\
& +B_{17}(\text { Geographic Property Location }) \\
& +B_{18}(\text { Waterfront })+B_{19}(\text { Transaction Month })+e .
\end{aligned}
$$


*This model is run separately for Built School Facility Age and Effective School Facility Age.

The model variables are defined as:

\section{Dependant Variable}

Selling Price: 2005 dollar amount of arms-length real estate transaction for owneroccupied, primary single-family detached residential housing.

\section{School Related Variables}

School Facility Age = 1) Categorical viable indicating year school building originally built/re-built ("built") \& 2) Average ("effective") facility age net square feet;

School Output $=$ Combination of academic year student achievements and standardized test scores, converted to a numeric value between 0-4, per Florida School Grades;

Title I Status = Federally labeled "disadvantaged" schools; binary variable (yes/no);

Student Minority Rate = Percentage of students who are not "White, non-Hispanic;"

Faculty Experience $=$ Average number of years faculty have been teaching;

Classroom Technology $=$ Ratio of modern (less than five years old) computers in the classrooms to students;

Class Size $=$ Teacher $/$ student ratio;

Facility Size $=$ Net square footage of school building(s);

School Capacity $=$ Net square feet per student, per school facility; and

School District $=$ Countywide school district where house is located; dummy variable.

\section{Housing Related Variables}

Proximate to Alt. School = Residential parcels within two (2) miles distance to a "school of choice" and/or parcels zoned to a magnet school; binary variable (yes/no);

Living Space of House = Total (adjusted) residential living space, in square feet;

Age of House $=2005$ minus year house originally built;

Lot Size $=$ Total size of residential property, in square feet;

Special Housing Features = Dollar amount of any recorded housing improvements (ex. pool);

Jurisdiction Service = Jurisdictional level per capita public service expenditures;

Fee Rate $=$ Divided by millage rate;

Geographic Property = Longitude and latitude of residential property location;

Waterfront $=$ Residential parcels that are adjacent to water; binary variable (yes/no); and

Selling Month $=$ Month of recorded housing transaction; dummy variable

\section{Measurement}

The dependant variable is the selling price of qualified arms-length transactions for owneroccupied, primary single-family detached residential housing in the Orlando, Florida area 
(Orange and Seminole Counties). All housing data are for 2005, from the 2006 Florida Department of Revenue: Final Real Property Tax Rolls. There are a total of 20,387 qualified observations, 13,953 in Orange County and 6,434 in Seminole. ${ }^{2}$ The average selling price in the sample is $\$ 287,745$, with a standard deviation of $\$ 139,056$ and a range from $\$ 75,000$ to $\$ 1$ million. ${ }^{3}$ Selling month is included in the model to control for the seasonality of housing transactions, which spike in the summer and help proxy for related time-on-market trends. Selling month is a dummy variable, based on the month of recorded home transaction during 2005.

Other housing control variables include the total indoor, heated and cooled, residential living space, in square feet; the age of house (in 2005); the total size of residential property, in square feet; the dollar amount of any recorded housing improvements such as a pool or gazebo; the jurisdictional level per capita public service expenditures divided by millage rate; the longitude and latitude of residential property location; whether or not the property is adjacent to water; the countywide school district the house is situated in; and whether or not the house is proximate to an alternative "school of choice."

Including adjusted residential living space in the model controls for housing size variations, which in turn will determine number of bedrooms and/or other size related housing attributes. Including the age of a house helps to control for structural and architectural trends and features associated with the respective time periods, such as hardwood floors in older homes, large master suites in newer, and so forth. The residential lot size controls for the size and associated value of the land. The lot size variable is obtained from the Florida Department of Revenue: Geographic Information System (GIS) parcel files, which correspond with the tax rolls. The natural logarithm was used for this predictor. The special features variable is the dollar amount of any recorded home improvement. Florida Department of Revenue does not report the specifics of the improvement, only the dollar value. However, this value helps to control for any "extra" housing features such as pools or gazebos.

The jurisdictional per capita level of public service expenditures divided by the millage rate is included to obtain the jurisdictional service fee rate. This controls for fixed jurisdictional effects by measuring public services received divided by the cost of those services. Annual jurisdictional public service expenditures and millage rates are available from the Florida Legislative Committee on Intergovernmental Relations. Jurisdictional figures are based on 2005 calculations, except for two municipalities in Orange County for which only 2004 data are available.

Also included is the geographic longitude and latitude of the residential property location to help capture variability associated with property location. Further, by examining the physical characteristics of the area, waterfront properties are identified and reported to control for associated waterfront premiums. These variables are also determined from the Florida Department of Revenue: GIS parcel files.

Dummy variables for the countywide school districts are included to control for additional countywide qualitative aspects that one may consider when purchasing a home. This may include institutional differences of school system quality. For example, one county may collectively be qualitatively perceived as having an overall "better" school system, even though schools within each county may still vary. Since school districts in Florida are countywide, there are two school districts in the sample. 
Under School Choice policy, a student may choose to apply to attend an alternative school in their district instead of their zoned school such as a private, charter, magnet school, or another public school altogether. This may offset negative externalities associated with low public elementary school quality in an area. Using the Florida Department of Education: Office of Independent Education \& Parental Choice School Directory and the Florida Department of Revenue: GIS parcel files, parcels within a two mile radial distance to a "school of choice" (private and/or charter) and parcels whose zoned school is a magnet school are identified as being proximate to an alternative school. ${ }^{4}$

Furthermore, under the federal No Child Left Behind Act of 2002, if a student is dissatisfied with their zoned school for various, prioritized, hierarchal sets of reasons, such as if a school fails to meet required Adequate Yearly Progress (AYP) gains, a student's parents may request a transfer of the student to another school in the district. Transfers are granted on an as-requested, as-needed, and as-available basis. Eligible schools to transfer to are limited based on fluctuating variables such as school grade, school capacity, and school location, and the transfer to the requester's school of 'first choice' is not guaranteed. Alternatively, corrective action may take place at the zoned school in lieu of a transfer (Florida School Choice Resource Center, 2008). So while a remedy may be mandated in certain instances, due to the unpredictable aspect of the School Choice program, with the school of transfer being uncertain to the homebuyer, the actual alternative school a child will attend is incalculable.

However, homes sold in areas with Title I schools (at the time of transaction-January 1 to August 21 with academic year 2004/05 and September 1 to December 31 with academic year 2005/06) are labeled as such in the model, as these are schools that have been identified under Title I of the federal Elementary and Secondary Education Act of 1965 as "disadvantaged," making them viable candidates from which to transfer. Collectively, labeling Title I schools and schools with low student outputs will help control for No Child Left Behind and School Choice policies (United States Department of Education, 2008, 2009). In addition, the Title I label of a school serves as a proxy for low neighborhood income composition, as it is a reflection of student's parental income via consideration of the free or reduced lunch rate at the school (United Stated Department of Education, 2009). A historical list of all Title I schools is available from the Florida Department of Education, Bureau of Student Assistance. Using the Florida Department of Revenue: GIS parcel files, school attendance zone was identified for each house. Each school zone was then matched with the Title I list for the appropriate academic year (correlating to the month of housing transaction).

Academic year 2004/05 and 2005/06 school attendance zone boundaries associated with 2005 housing transactions are provided by county and school district GIS departments (Orange County Public Schools and Seminole County Public Schools). Due to some school redistricting in Orange County between school year 2004/05 and 2005/06, coordination of the transaction month and school year attendance zone boundary is required. Academic year 2005/06 school redistricting adoptions in Orange County took place during January 11 and 25, 2005 School Board Meetings. Orange County housing transactions during the month of January 2005 coordinate with school year 2004/05 boundaries and transactions that occurred in February and beyond coordinate with school year 2005/06 boundaries because this is the information that would have been attainable to home shoppers at the 
time of entering into a contract. There is no change in elementary school attendance zones in Seminole County from 2004/05 to 2005/06.

The independent variable of particular interest in this study is school facility age. School facility age is defined and measured in two ways: both 1) by the year the school building was originally built/opened or the most recent year the facility was fully re-built/reopened when applicable, and 2) the average effective age of the facility's net square feet. A full re-build constitutes a comprehensive renovation of the entire facility from the ground up, not basic maintenance or minor improvements and/or additions that are captured in the effective age.

The 2008 Florida Department of Education, Florida Inventory of School Houses (FISH) Facility Inventory Reports were used to determine a school facility's age, both built and effective. This report itemizes each facility room by room, and lists the room's function, size in square feet, date originally built, and the date and description of any and all updates to that room. Each facility was reviewed carefully to determine the original and effective ages. The original age is simply the year the school opened, but the effective age is the weighted average of the built facility.

For both varieties, school ages are grouped into ordinal scales with descriptive labels for analysis. The reason analysis included ordinal categories of age instead of actual age because school facility age does not have a direct linear relationship with housing selling price. For example, the difference in value between 1978 and 1979 is not equal to 1998 and 1999. Instead however, the schools may be conceptually grouped as either "late 1970s" schools or "late 1990s" schools, respectively; or more simply, "newer" or "older," respectively. It is the ordinal categorical differences that are being measured in this study. To measure the categorical differences, the school ages are grouped into ordinal categories with descriptive labels and included in the model as dummy variables (Agresti and Finlay, 1997).

For the year built, the decades are paired off and the categories created are 1) newer schools, any school built during the 1990s and after, 2) middle-aged schools, any school built in the 1970s or 1980s, 3) older schools, any schools built in the 1950s or 1960s, and 4) historic schools, any school built prior 1950. The pairing of decades makes the most sense for analyzing "newer schools," the category of interest, as there are only approximately a half decade of new millennium schools at the time (2000 to 2004/2005). The problematic issue with this is that a 1998 school, while not a new millennium school, is still less than a decade old at the time of the sample and thereby still considerably "newer" to consumers. Several different categorical breaks are considered to address this issue, including decade and mid-decade breaks, but simply adding the most recent full decade with the new millennium schools (1990-2005) proves effectively efficient and intuitive for interpreting the findings. From there the subsequent decades are paired for consistency purposes until the historic school category is reached, which is a grouping of all pre-1950 schools, due to lack of quantity in this category.

There are a total of 141 elementary school facilities, and four "built" age categories. The newer school category includes 48 facilities and is expected to be strongly positively associated with housing price. The middle-aged category includes 28 facilities and is expected to be mildly positively associated with housing price. The older school category 
includes 58 facilities and is expected to be mildly negatively associated with housing price. The historic school category includes only seven facilities and is expected to be strongly negatively associated with housing price.

For the average "effective" age, the elementary schools are grouped either as 1) "current," any school with an average effective facility age in the 1990s or after, or 2) "not-current," any school with an average effective facility age prior to 1990. The median average school age for the sample is 1991 and the mean is 1987, thus 1990 is the decade break in-between the median and the mean. This makes the cut-off of "newness" the same (1990) for both built and effective school age. There are 61 labeled "current" facilities and 80 "not-current" facilities. It is expected that the current facilities will have a strong positive relationship with home selling prices compared to their counterpart.

Other school control variables include school outputs; student race composition; faculty experience; the ratio of modern computers in the classrooms to students; teacher/student ratios; the net square footage of school building(s); and the net square footage per student, per school facility.

The school output variable is derived from the Florida Department of Education School Grade. Florida School Grade assignments are administrated at the countywide school district level under the supervision of the Florida Department of Education. Like most student grading scales, School Grades range from "A" to " $F$," with "A" being the best and " $F$ " the worst (with no "E" grade). School Grades are assigned based on a combination of an accumulation of points earned by student achievements on the Florida Comprehensive Assessment Test (FCAT), percentage of students tested, and the No Child Left Behind Act, Adequate Yearly Progress (AYP) criteria (Florida Department of Education 2007). Grades for all Florida schools are published annually by the Florida Department of Education in School Accountably Reports, which are made available to the public on the Florida Department of Education website. Academic year 2004/05 School Grades were publicly available as of June 8, 2005.

The Florida Department of Revenue tax rolls indicate month of housing transaction, but not the day. In addition, there is generally a lag time between the day of a transaction and when the contract is actually entered into agreement. To compensate for this lag time, transactions that occur during January 2005 through June 2005 associate with academic year 2003/04 School Grades and transactions that occur during July 2005 through December 2005 associate with academic year 2004/05 School Grades. All School Grades are converted to a numeric value for analysis ( $A$ " $=4$, "B" $=3$, "C" $=2$, "D" $=1$, and " $F "=0$ ). For purpose of clarity, the Florida Department of Education School Grade is hereby referred to as the "school output."

A school's student minority rate, measured in percentage, controls for school and neighborhood race composition. A school's student minority rate reflects the percentage of students who are not listed as "White, non-Hispanic" in that school. Data for this variable are published annually in Florida Department of Education School Accountably Reports and the data for academic year 2003/04 or 2004/05 are used for analysis, again depending on the date of the house transaction relative to the publication of the report (academic year 2003/04: January-June transaction; academic year 2004/05: JulyDecember transaction). 
Faculty (teacher) qualities can be measured in various ways; however, the measure viewed as the most attainable to the home shopping public (thereby most likely influencing a home's selling price) is experience. Experience is also a consistently discussed variable for purposes of faculty quality discourse. Faculty experience is a teacher's experience, measured in years. This is the quality measure that the state of Florida and local school districts use for determining teacher pay scale, and these (experience and pay scale) figures are widely available to the public on associated state, county and local school websites. This teacher "quality" is recorded annually in each district's schools, in accordance with No Child Left Behind, School Public Accountability Report requirements. Faculty experience data are obtainable from the Florida Department of Education, Division of Accountability, Research, and Measurement data warehouse. This information is collected twice a year, October and February, and made publicly available in March (based on the February collection). Homes sold during March and prior in 2005 had access to 2003/04 academic school year data and homes sold in April and after had access to the 2004/05 school year data. Academic year used for analysis correlates with date of home transaction.

The System for Technology Accountability and Rigor (STAR) survey is administered in October/November of each year by Florida Innovates and available to the public on March 1 of the following year. The October 2003 STAR survey was available to homebuyers in March 2004 and the 2004 STAR survey in March 2005. January 2005 to March 2005 home transactions associate with the 2003 survey and April 2005 to December 2005 associate with the 2004 survey, factoring for contract to transaction lag time.

Student access to technology is the ratio of modern computers (less than five years old at time of survey that are Internet and multimedia capable) in the school's classrooms for student use divided by the student enrollment at the time of the STAR survey. Students spend the majority of their time in "regular" educational classrooms as opposed to other locations, such as computer labs or media centers, and therefore Florida Innovates advocates that this figure is a good indicator of student technology access, thereby letting this variable give a valid snapshot of how technology is integrated into daily curriculum by way of indicating of how much technology students have access to during the bulk of the school day. This variable is labeled classroom technology.

School enrollment information is available to homebuyers in a timely manner. Enrollment counts are taken throughout the academic school year, but the October (aka. "Survey 2") figures are commonly used by the Florida Department of Education as the "official" count for research analysis purpose and therefore the Survey 2 counts are used for analysis in this study. January through October transactions correspond with 2004/05 school year enrollments and November and December transactions correspond with 2005/06 school year enrollments. Because Florida Department of Education (per) class size reports did not begin in Seminole County until school year 2006/07, class size is measured as an overall student/teacher ratio in this study. This ratio considers the student counts from the October (Survey 2) numbers. Homes purchased in October or prior associate with school year 2004/05 counts and homes purchased in November or December use 2005/ 06 counts. October teacher counts are obtained from the 2005/05 and 2005/06 STAR surveys. Facility net square footage is based on the net square footage listed in the Florida 
Exhibit 2. Descriptive Statistics of the Housing Variables

\begin{tabular}{|c|c|c|c|c|}
\hline Variable & $\begin{array}{l}\text { Mean / } \\
\text { Percent }\end{array}$ & Std. Dev. / Freq. & Min. & Max. \\
\hline Selling price & $287,745.20$ & $139,055.80$ & 75,000 & $1,000,000$ \\
\hline School facility built year & 1981.61 & 17.73 & 1924 & 2005 \\
\hline School facility effective year & 1986.91 & 13.13 & 1943 & 2005 \\
\hline School output $(N=19,034)$ & 3.60 & 0.73 & 0 & 4 \\
\hline Title I status & $26.07 \%$ & 5,315 & 0 & 1 \\
\hline Student minority rate $(N=19,034)$ & 49.91 & 20.57 & 9 & 100 \\
\hline Faculty experience $(N=19,200)$ & 12.03 & 2.68 & 6.54 & 18.98 \\
\hline Classroom technology $(N=18,428)$ & 0.12 & 0.08 & 0 & 0.53 \\
\hline Class size $(N=19,501)$ & 0.07 & 0.01 & 0.05 & 0.14 \\
\hline Facility size & $86,110.57$ & $26,474.45$ & 19,980 & 148,213 \\
\hline School capacity $(N=19,501)$ & 106.64 & 36.72 & 18.18 & 250 \\
\hline School District & & & 0 & 1 \\
\hline Orange & $68.44 \%$ & 13,953 & & \\
\hline Seminole & $31.56 \%$ & 6,434 & & \\
\hline Proximate to alternative school & $30.07 \%$ & 6,130 & 0 & 1 \\
\hline Living space of house & $2,296.30$ & 841.05 & 612 & 10,196 \\
\hline Age of house & 12.51 & 13.46 & 0 & 85 \\
\hline Lot size & $11,271.18$ & $15,847.76$ & 457.29 & $514,075.10$ \\
\hline Special housing features & $6,097.71$ & $9,057.96$ & 0 & 64,750 \\
\hline Jurisdictional service fee rate & 427.90 & 222.86 & 257.79 & $1,298.43$ \\
\hline Waterfront & $5.83 \%$ & 1,189 & 0 & 1 \\
\hline Selling Month & & & 0 & 1 \\
\hline January & $5.94 \%$ & 1,211 & & \\
\hline February & $7.42 \%$ & 1,513 & & \\
\hline March & $9.56 \%$ & 1,949 & & \\
\hline April & $8.79 \%$ & 1,792 & & \\
\hline May & $9.18 \%$ & 1,872 & & \\
\hline June & $10.45 \%$ & 2,131 & & \\
\hline July & $9.20 \%$ & 1,876 & & \\
\hline August & $9.50 \%$ & 1,937 & & \\
\hline September & $8.57 \%$ & 1,747 & & \\
\hline October & $6.92 \%$ & 1,410 & & \\
\hline November & $7.24 \%$ & 1,477 & & \\
\hline December & $7.22 \%$ & 1,472 & & \\
\hline
\end{tabular}

Notes: $N=20,387$ unless otherwise noted.

Department of Education, Florida Inventory of School Houses (FISH) Facility Inventory Reports. This is the figure used to determine overall facility size. School capacity is measured by total student enrollment, divided by net facility square footage. Exhibit 2 displays descriptive statistics for all model variables.

Before analysis, standard Ordinary Least Squares (OLS) assumptions are checked. Upon visual inspection, selling price and lot size appear to be positively skewed. Due to the central limit theorem, which states that for large samples the distributions of the averages will approach normal regardless of the sample's distribution shape, this is not a concern (Agresti and Finlay, 1997). However, lot size warrants a transformation as this variable lacks a linear relationship with selling price. The average lot size in the study area is just over a quarter of an acre, and nearly $73 \%$ of all parcels are smaller than the mean, lacking 


\section{Exhibit 3. Elementary School Facility Age Category Findings}

\begin{tabular}{llll} 
Category & Timeframe & $\begin{array}{l}\text { Hypothesized Directional } \\
\text { Relationship with } \\
\text { Housing Price }\end{array}$ & $\begin{array}{l}\text { Found Directional } \\
\text { Relationship with } \\
\text { Housing Price }\end{array}$ \\
\hline $\begin{array}{l}\text { Newer schools (vs. non-newer } \\
\text { schools) }\end{array}$ & 1990s \& 2000s & ++ & + \\
$\begin{array}{l}\text { Middle-aged schools (vs. newer) } \\
\text { Older schools (vs. newer) }\end{array}$ & $\begin{array}{l}1970 \text { s \& 1980s } \\
\text { Historic schools (vs. newer) }\end{array}$ & + & - \\
\hline
\end{tabular}

Notes: Number of pluses or minuses symbolize relative magnitude.

in a constant variance. To compensate for this it is determinable through trial and error procedures that the logarithm gives lot size the most improved linear relationship with selling price. The natural logarithm of lot, size_log, is used in the analysis. No other variables are transformed from raw form. ${ }^{5}$

Testing for multicollinearity by using a variance inflation factor (vif) test, all scores are under four and thereby acceptable. ${ }^{6}$ Testing for spatial autocorrelation, a Moran's I (index of spatial autocorrelation) score is $\mathbf{0 . 0 9 1 6}$, indicating a fairly random distribution within the sample (Mitchell, 1999). A Breusch-Pagan/Cooks-Weisberg test for heteroscedasticity indicates a lack of constant variance in the model. The prescription of using robust standard errors is applied to down-weight influential observations in the regression (Hoffman, 2004; Chatterjee, 2006). ${ }^{7}$ No other measurement issues are indentified.

\section{Results}

Newer schools versus non-newer schools (of all categories) results in a positive coefficient (13,381.19), significant at alpha level .001 when using robust standard errors (s.e. = 1,567.291). This is an expected result. However, what is not expected is when newer schools are the reference category, the directional pattern is not inverse with age. Instead the school facility age categories present a U-shaped pattern. The newer elementary schools seem to be positively attractive to consumers, the middle-aged elementary schools negatively attractive, older elementary schools insignificant, and the historic elementary schools again attractive at an even greater magnitude than for newer schools.

With the $F$-statistic resulting in a low $P$-value (0.000), the null hypothesize of school (built) age categories not having importance is rejected, which indicates that these elementary school age categories do matter to housing price. ${ }^{8}$ Exhibits 3 and 4 display the findings.

Even though the U-shaped pattern is not expected, it does make sense that consumers will be attracted to both newer and historic schools. Research in the field of consumer psychology and marketing indicates that in addition to new products, consumers also hold nostalgic preferences for historic products. This principle is applicable to many consumer goods such as music, movies, housing or automobiles (Schindler and Holbrook, 2003). For illustration, assume three red convertible Ford Mustangs drive into a crowded 


\section{Exhibit 4. Elementary School Regression Outputs-Built Age Categories}

\begin{tabular}{lcrl} 
Predictor & Coeff. & Std. Error & $P$-value \\
\hline Newer schools & Reference Category & & \\
Middle-aged schools & $-18,967.17$ & $1,603.89$ & $0.000^{*}$ \\
Older schools & $1,414.699$ & $1,897.553$ & \multicolumn{1}{l}{0.456} \\
Historic schools & $35,707.72$ & $4,630.235$ & $0.000^{*}$ \\
School output & $2,964.678$ & 917.845 & $0.001^{*}$ \\
Title I status & $-15,657.06$ & $1,898.071$ & $0.000^{*}$ \\
Student minority rate & -340.045 & 50.351 & $0.000^{*}$ \\
Faculty experience & $2,308.954$ & 310.944 & $0.000^{*}$ \\
Classroom technology & $41,721.38$ & $7,590.90$ & $0.000^{*}$ \\
Class size & $537,225.1$ & $79,213.51$ & $0.000^{*}$ \\
Facility size & -0.086 & 0.038 & $0.022^{* *}$ \\
School capacity & -139.817 & 24.580 & $0.000^{*}$ \\
Seminole County (versus Orange County) & $30,923.24$ & $2,002.965$ & $0.000^{*}$ \\
Proximate to alternative school (versus not proximate) & $-6,427.45$ & $1,305.971$ & $0.000^{*}$ \\
Living space of house & 111.650 & 1.602 & $0.000^{*}$ \\
Age of house & -32.498 & 58.892 & 0.581 \\
Lot size_log & $6,984.866$ & $1,322.56$ & $0.000^{*}$ \\
Special housing features & 2.875 & 0.101 & $0.000^{*}$ \\
Jurisdictional service fee rate & 62.137 & 3.367 & $0.000^{*}$ \\
Waterfront & $21,087.68$ & $3,472.152$ & $0.000^{*}$ \\
\hline Notes: The dependent variable is selling price; $N=18,428$ houses (with 136 associated possible elementary \\
schools). & & & \\
F(32, 18395$)=708.57$ & & & \\
Probability $>$ F = 0.0000 & & & \\
Adjusted R-square $=0.7223$ & & & \\
* Significant at the 0.01 level. & & & \\
** Significant at the 0.05 level. & & &
\end{tabular}

parking lot: one is brand new; one is a collector's 1967 model; one is a mid-1980s model. It is likely that one group of people will be attracted to the "new" shiny car, one group of people attracted to the "classic" retro car, and most folks will be fairly indifferent to the "middle-aged" 1980 s vehicle, as there is nothing 'special' about it. This phenomenon may be called a "Mustang Effect."

While school age appears to display a Mustang Effect, it is important to point out that in addition to nostalgia, institutional legacy may also be helping to drive this phenomenon. For example, a historic community school that is deemed to be of good quality and keeps up such reputation year after year will likely eventually create a positive legacy for itself. Thus, in an essence, the legacy will serve as a proxy for quality. Furthermore, legacies will work in both directions, positive and negative, so schools with negative legacies may be likely to close down before ever reaching historic status. Thus, there may be a "Mortality Effect." The positive and negative effects of legacy and preferences are not 
well documented in literature. Therefore, it is not completely clear as to the interplay between nostalgia and legacy for school facility age, and it is being suggested that this phenomenon warrants further exploration in future studies.

It is important to keep in mind, however, that while historic schools had a significant positive association with housing values, not all historic schools have higher student achievements (school outputs). In fact, there is a range of output fluctuation for historic schools, as there is for all the school age categories. Thus there is no considerable school output difference between categories. Consequently, a "Mustang Effect" seems more likely than a "Mortality Effect" in this case.

When analyzing school facility age, a slightly different story unfolds. In this scenario, elementary schools with current effective ages are more strongly and significantly positively associated with housing prices. Effectively "current" schools (average age newer than 1990) result a positive coefficient (13,657.61) significant at alpha level .001 when using robust standard errors (s.e. $=1,338.05$ ). This is an expected result. Again the $F$-statistic results in a low $P$-value (.000) and the null hypothesize of school age categories not having importance is rejected, indicating that the elementary school age also matters to housing price. ${ }^{9}$

This finding is important because it means that the upper fiftieth percentile (median average age 1991) facilities by school facility age strongly, positively, and significantly correlate to higher housing costs in the sample. This indicates that there is perhaps an inequitable distribution of modern school facilities in the study area because higher home costs are associated with overall newer facilities. The consequence of this is that lower income families may have less access to the more modernized school facilities. Being that other researchers have previously found school conditions to influence education achievements, this unbalanced distribution of facilities may be hindering to those students who attend less modern schools, children from lower socio-economic households (Summers and Wolfe, 1977; Plumley, 1978; Betts, 1995; Bowers and Burkett, 1987; Cash, 1993; Chan, 1979; Ikpa, 1992; Hines, 1996; Harter, 1999; Morgan, 2001; Schneider, 2002).

The findings displayed here pertain to only public elementary schools; however, analysis of middle and high schools results in fairly similar findings. These findings do not directly dispute previous studies regarding school quality on housing price/choice, rather they add to the discourse on the matter. There is still little reason to doubt the notion that school quality is associated with housing price. However, there is reason to question which specific school attributes are more important to housing consumers when making a housing choice. Categorical school age is a relatively easy attribute to obtain by housing consumers.

\section{Conclusion}

This research provides evidence that housing prices are associated with school facility age in some manner. Calculating the monetary impact of newer schools on housing price in the sample, when all other attributes are held constant, it is observable that a home zoned for a newer built elementary school sells for $\$ 13,381.19$ more on average and a home zoned for an (effectively) current elementary school sells for $\$ 13,657.61$ more on 
average; so whether the built age or the average age is considered, newer school facilities (newer than 1990 in 2005) added sufficient value to housing prices. This further supports the notion that a home's associated public school facility age is thought to be considered important not just to households with children in the public school system, but to all housing consumers for the purposes of resale value capitalization (Jud and Watts, 1981; Briggs, 2005).

Cities like Atlanta (GA), Chattanooga (TN), Cincinnati (OH), Pomona (CA), Philadelphia (PA), and St. Louis (MO) all indicate that school investment has helped "jump-start" desirability in their community development initiatives (Varady and Raffel, 1995; Myerson, 2001; Weiss, 2004). The findings from this study empirically suggest it is completely plausible that by including new schools in community revitalization projects, the schools could indeed help jump-start and/or sustain revitalization of communities linked with the facility. In addition, the findings suggest that the revitalization of historic school facilities may produce similar results due to the observed relationship between housing prices and historic schools.

There is still uncertainty as to the overall direction of causality between housing choice and school quality and it is not being suggested that school facilities are a "silver bullet" capable of "magically" revamping depressed communities. However, it is the implication that school facilities may be an important component to the community revitalization and sustentation equation via the relationship between school facility age and housing price. The implication is that if communities continue to invest in new schools, or renovate existing schools in older communities, then this action could aid in community development initiatives and urban revitalization efforts in those neighborhoods. Consequently, and of equal importance, the lack of school investment in other parts of a region could aid in economic decline in those areas, and help perpetuate regional socioeconomic community divisions. In conclusion, school facility planning is a subject that must be addressed carefully, with the recognition that all benefits and/or consequences have the potential to be felt by every household in the community.

\section{Endnotes}

1 The United States Census Bureau includes Lake and Osceola Counties in the Orlando Metropolitan Statistical Area in addition to Orange and Seminole, but 2005 school boundary Geographic Information System data are not available at the time of this study for these two peripheral counties (U.S. Census, 2008).

${ }^{2}$ Incomplete cases were not included in the analysis.

${ }^{3}$ Housing price outliers beyond box plot whiskers are not included in the analysis, so the sample range may more characteristically represent housing transactions for the population.

${ }^{4}$ A distance of two miles is chosen for this measure pursuant to Florida Administrative Code 6A-3.001, Basic Principles for Transportation of Students, which determines two miles as a "reasonable walking distance for any student" not requiring special consideration under Section 1011.68 Funds for Student Transportation in the Florida Statutes; and thus school districts are not mandated to provide transportation within this zone (Florida Department of Education, 2008). Under this line of thought, parents will not need to find transportation to alternative schools within two miles of home because the children can walk unless, again, 
special conditions are in play such as hazardous road conditions or a student disability; in which case, two miles may still be considered quite proximate.

5 Log-linear regression resulted in no significant differences in the outputs.

6 The percentage of students in a school receiving a free or reduced lunch is originally included in the model to control for school and neighborhood SES composition. The percentage of a school's students on free or reduced lunch reflects all students who receive any amount of meal subsidization in that school. This is a "yes" or "no" dichotomous variable. However, during the variance inflation factor (vif) testing, a strong multicollinearity problem between the free or reduced lunch and the student minority rate variables is found. Free or reduced lunch has a vif score of 10.06 and student minority rate 8.70 . Free or reduced lunch and the student minority rate variables appear to have a close linear relationship at the elementary school level in this sample. The Title I variable (federal labeling of "disadvantaged" schools) already takes into consideration the free or reduced lunch rate of the school (United States Department of Education, 2009). It is also understood that free or reduced lunch rates can often be less than accurate. Because of its problematic unreliable nature and due to the fact that this socio-economic (low income) variable is in essence already being accounted for by the Title I label, school free or reduced lunch rate is dropped from the model while student minority rate and Title I status are kept.

${ }^{7}$ Because the study is analyzing aggregate school data at the micro unit level of housing selling price, additional analysis is applied with the standard errors clustered at the school zone level to correct for possible common random group effects which can result in a downward bias in the errors. Robust-clustering results in a cautious estimate of standard errors in effort to avoid spurious findings of significant relationships (Moulton, 1990). Because of this cautiousness, any significant findings may be stated with a fairly strong certitude. However, the flipside to this approach is the possibility of underestimating effects. No school age categories were significant at alpha level .1 when the standard errors were clustered at the school zone level. This does not change the conclusion.

8 If socio-economic variables are further controlled for by assessing only non-Title I and lowminority schools, this relationship pattern becomes even stronger in significance.

9 Number of observations $=18,428 ; \mathrm{F}(30,18397)=737.59$; Adjusted R-squared $=0.7189$.

\section{References}

Agresti, A. and B. Finlay. Statistical Methods for Social Sciences. Third edition. Upper Saddle River, New Jersey: Prentice Hall, 1997.

Baum, H.S. Smart Growth and School Reform: What If We Talked About Race and Took Community Seriously. Journal of the American Planning Association, 2004, 70:1, 14-26.

Betts, J.R. Does Schools Quality Matter? Evidence from the National Longitudinal Survey of Youth. Review of Economics and Statistics, 1995, 77, 231-50.

Birger, J. Can the Economy Survive the Housing Bust? Fortune, November, 2006.

Black, S. Do Better Schools Matter? Parental Valuation of Elementary Education. Quarterly Journal of Economics, 1999, 114:2, 577-99.

Bogart, W.T. and B.A. Cromwell. How Much More Is a Good School District Worth? National Tax Journal, 1997, 50, 215-32.

Bowers, J.H. and G.W. Burkett. Relationship of Student Achievement and Characteristics in Two Selected School Facility Environmental Settings. Paper presented at Edmonton, Alberta, Canada: 64th Annual International conference on the Council of Educational Facility Planners, 1987.

Bradbury, K.L., K.E. Case, and C.J. Mayer. School Quality and Massachusetts Enrollment Shifts in the Context of Tax Limitations. New England Economic Review, 1998, July, 3-20. 
Brasington, D.M. and D.R. Haurin. Educational Outcomes and House Values: A Test of the Value Added Approach. Journal of Regional Science, 2006, 46:2, 245-86.

Briggs, X. (editor). The Geography of Opportunity: Race and Housing Choice in Metropolitan Community. Washington D.C.: Brookings Institution Press, 2005.

Cash, C. Building Conditions and Student Achievement and Behavior. Ph.D. Dissertation, Virginia Polytechnic Institute and State University, 1993.

Chan, T.C. The Impact of School Building Age on Pupil Achievement. Report, Office of School Facilities Planning, Greenville (South Carolina) School District, 1979.

Chatterjee, S. and A. Hadi. Regression Analysis by Example. Hoboken, NJ: John Wiley and Sons, 2006.

Clark, D.E. and W.E. Herrin. The Impact of Public School Attributes on Home Sale Prices in California. Growth and Change, 2000, 31, 385-407.

Diyab, A. 1984. Housing Value, School Quality and the Probably Of Sale: An Application of Hedonic Method. Ph.D. Dissertation, Florida State University, 1984.

Downes, T.A. and J.E. Zabel. The Impact of School Characteristics on House Prices: Chicago 1987-1991. Journal of Urban Economics, 2002, 52, 1-25.

Figlio, D. and M. Lucas. What's in an Output? School Report Cards and the Housing Market. American Economic Review, 2004, 94:3, 591-604.

Fischel, W. The Homevoter Hypothesis. Cambridge, MA: Harvard University Press, 2000.

Florida Department of Education. Grading Florida Public Schools. Retrieved from the web October 2007: http://schoolgrades.fldoe.org/pdf/0607/School_Grades_07_PressPack12.pdf.

- Guide to Calculating School Grades. Technical Assistance Paper. Retrieved from the web April 2008: http://schoolgrades.fldoe.org/pdf/0607/2007SchoolGradesTAP.pdf.

Florida School Choice Resource Center. Information retrieved from the web March 2008: www.fgse.nova.edu/choice/options/public_choice.htm\#control_open.

Goodman, A.C. and T.G. Thibodeau. Housing Market Segmentation. Journal of Housing Economics, 1998, 7:2, 121-43.

Gurwitt, R. Edge-ucation: What Compels Communities to Build Schools in the Middle of Nowhere? Governing: The Magazine for State and Localities, 2004, March, 22-6.

Harrison, K.L. Equity in Florida's Capital Infrastructure Financing for Public K-12 Schools. Action Report, Florida State University, 2006.

Harter, E.A. How Education Expenditures Relate to Student Achievement: Insights From Texas Elementary Schools. Journal of Education Finance, 1999, 24:3, 281-302.

Haurin, D.R. and D.M. Brasington. The Impact of School Quality on Real House Prices: Interjurisdictional Effects. Journal of Housing Economics, 1996, 5, 351-68.

Hayes, K.J. and L.L. Taylor. Neighborhood School Characteristics: What Signals Quality to Homebuyers? Federal Reserve Bank of Dallas: Economic Review, 1996, Fourth Quarter, 29.

Hines, E. Building Condition and Student Achievement and Behavior. Ph.D. Dissertation, Virginia Polytechnic Institute and State University, 1996.

Hoffman, J. Generalized Linear Models: An Applied Approach. Boston, MA: Pearson Education, 2004.

Ikpa, V.W. The Norfolk Decision: The Effects of Converting from a Unitary Educational System to a Dual Educational System upon Academic Achievement. Norfolk, VA: Norfolk City Schools, 1992.

Jud, G.D. and J.M. Watts. Schools and Housing Values. Land Economics, 1981, 57:3, 459-70.

Kain, J.F. and J.M. Quigley. Measuring the Value of Housing Quality. Journal of the American Statistical Association, 1970, 65, 532-46. 
LaCour-Little, M. and S. Malpezzi. Gated Streets and Housing Prices. Journal of Housing Research, 2009, 18:1, 19-43.

Li, M. and H.J. Brown. Micro-Neighborhood Externalities and Hedonic Housing. Land Economics, 1980, 56, 125-41.

Mitchell, A. The ESRI Guide to GIS Analysis. Redlands, CA: ESRI Press, 1999.

Morgan, L. Facility Conditions and Student Test Performance in the Milwaukee Schools. Scottsdale, AZ: Council of Educational Facilities Planners International, 2001.

Moulton, B.R. An Illustration of a Pitfall in Estimating the Effects of Aggregate Variables on Micro Units. Review of Economics and Statistics, 1990, 72:2, 334-38.

Myerson, D.L. 2001. Sustaining Urban Mixed-Income Communities: The Role of Community Facilities. The ULI/Charles H. Shaw Annual Forum on Urban Community Issues, October 1819.

Plumley, J.P. The Impact of School Building Age on the Academic Achievements of Selected Fourth Output Pupils in the State of Georgia. Athens, GA: University of Georgia, 1978.

Reback, R. House Prices and the Provision of Local Public Services: Capitalization Under School Choice Programs. Journal of Urban Economics, 2005, 57:2, 275-301.

Schindler, R.M. and M.B. Holbrook. Nostalgia for Early Experience as a Determinant of Consumer Preferences. Psychology \& Marketing, 2003, 20:4, 275-302.

Schneider, M. Do School Facilities Affect Academic Outcomes? Washington D.C: National Clearinghouse for Educational Facilities, 2002.

Seo, Y. and R. Simons. The Effects of School Quality on Residential Sales Prices. Journal of Real Estate Research, 2009, 31:3, 307-27.

Sirmans, G., D. Macpherson, and E. Zietz. The Composition of Hedonic Pricing Models. Journal of Real Estate Literature, 2005, 12:1, 3-43.

Summers, A. and B. Wolfe. Do Schools Make a Difference? The American Economic Review, 1977, 674, 639-52.

Tiebout, C. A Pure Theory of Local Expenditures. Journal of Political Economy, 1956, 64, 416-24.

United States Census Bureau. American Community Survey Press Release, May 22, 2007.

United States Census Bureau. Population Estimates. 2003 and 2005. Retrieved from the web April 2008: www.census.gov/.

United States Department of Education. Title I-Improving the Academic Achievement of the Disadvantaged. Information retrieved from the web March 2008 \& February 2009: www.ed.gov/policy/elsec/leg/esea02/pg1.html.

United States Department of Housing and Urban Development. Homeownership and Its Benefits. Urban Policy Brief, 1995, August, 2.

Varady, D.P. and J.A. Raffel. Selling Cities: Attracting Homebuyers Through Schools and Housing Programs. New York: State University of New York Press, 1995.

Weimer, D. and M. Wolkoff. School Performance and Housing Values: Using Non-Contiguous District and Incorporation Boundaries to Identity School Effects. National Tax Journal, 2001, 54:2, 231-53.

Weiss, J. Public Schools and Economic Development: What the Research Shows. Cincinnati, OH: KnowledgeWorks Foundation, 2004.

Wetzel, J.N. Schools and Housing Values: Comment. Land Economics, 1983, 59:1, 131-34.

Huston Gibson, Kansas State University, Manhattan, KS 66506 or hgibson@k-state.edu. 
Reproduced with permission of the copyright owner. Further reproduction prohibited without permission. 